\title{
Physical activity of children and youth with disabilities
}

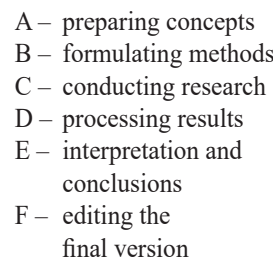

\section{Aktywność fizyczna dzieci i młodzieży $z$ niepełnosprawnością}

\author{
Kaja Piłatowicz A-F, Marta Kinga Zdunek B-F, Bartosz Molik ${ }^{\mathrm{D}-\mathrm{F}}$, \\ Agnieszka Magdalena Nowak F, Jolanta Marszałek A-F
}

Faculty of Rehabilitation, Chair of Movement Teaching, Department of Movement Teaching for the Disabled, Jozef Pilsudski University of Physical Education in Warsaw; Wydział Rehabilitacji, Katedra Nauczania Ruchu, Zakład Sportu Niepełnosprawnych, Akademia Wychowania Fizycznego Józefa Piłsudskiego w Warszawie

https://doi.org/10.5114/areh.2018.83394

\section{Abstract}

Introduction: Physical activity is defined as every movement performed by skeletal muscles above resting metabolic rate. It is important for children and youth as it contributes to appropriate emotional, social and somatic development. It may be limited by developmental disorders, diseases and disabilities. The aim of the work was to review the literature regarding physical activity of children and youth with motor disabilities.

Material and methods: The literature review was performed with the use of EBSCO and PubMed databases. The study inclusion criteria were as follows: publication in the English, Spanish or Polish language (1), abstract and/or title of the work included phrases "physical activity" and "children" and "disability" or "children with disabilities" and "fitness" and "activity" or "performance" and "children with disabilities" and "physical activity" (2), the work was published in the years 2011-2018 (3), it is available as a full -text article (4) and it comes from a scientific journal (5).

Results: As a result of the literature review, 516 articles were found, out of which 66 were found in EBSCO and 450 in PubMed. Ultimately, 35 papers which fulfilled the inclusion criteria (27 original articles and 8 reviews) were qualified for the study.

Conclusions: Persons with disabilities take up any forms of physical activity considerably less frequently than functionally fit individuals. Barriers which hinder taking up physical activity by children with disabilities are constituted mainly by environmental, psychological and physical factors. In order to assess physical activity of children and youth with disabilities, accelerometers, endurance tests, participation and quality of life questionnaires and interviews are applied most frequently.

Key words: $\quad$ physical activity, children and youth with disabilities, adaptation, disability

\section{Streszczenie}

Wstęp: Aktywność fizyczna to każdy ruch wykonany przez mięśnie szkieletowe organizmu powyżej tempa metabolizmu spoczynkowego. Jest ona ważna dla dzieci i młodzieży, gdyż kształtuje prawidłowy rozwój emocjonalny, społeczny i somatyczny. Może być ograniczona przez zaburzenia rozwojowe, choroby oraz niepełnosprawność. Celem pracy był przegląd piśmiennictwa dotyczący aktywności fizycznej podejmowanej przez dzieci i młodzież z niepełnosprawnością narządu ruchu. 
Słowa kluczowe:

Materiał $i$ metody: Przegląd piśmiennictwa został wykonany w bazach EBSCO oraz PubMed. Kryteriami włączenia było: praca musiała być publikowana w języku angielskim, hiszpańskim lub polskim (1), streszczenie i/lub tytuł pracy musiało zawierać słowa kluczowe: „physical activity” i „,children” i ,disability” lub „,children with disabilities” i ,fitness" i ,activity” lub ,performance” i ,children with disabilities” i ,physical activity" (2), praca musiała być wydana w latach 2011-2018 (3) oraz być dostępna w formie pełno-tekstowego artykułu (4), a także pochodzić z czasopisma naukowego (5).

Wyniki: W wyniku przeglądu piśmiennictwa znaleziono 516 artykuły, z czego 66 w bazie EBSCO, a 450 w bazie PubMed. Ostatecznie zakwalifikowano 35 prac spełniających kryteria włączenia, w tym 27 prac oryginalnych i 8 prac przeglądowych.

Wnioski: Osoby z niepełnosprawnością zdecydowanie rzadziej podejmują jakiekolwiek formy aktywności fizycznej niż osoby całkowicie sprawnie funkcjonalnie. Barierami utrudniającymi podejmowanie aktywności fizycznej dzieciom z niepełnosprawnością są przede wszystkim czynniki środowiskowe, psychologiczne i fizyczne. W celu oceny aktywności fizycznej dzieci i młodzieży z niepełnosprawnością, najczęściej stosowane są akcelerometry, testy wysiłkowe, kwestionariusze uczestnictwa i jakości życia oraz prowadzona jest rozmowa w formie wywiadu.

aktywność fizyczna, dzieci i młodzież niepełnosprawna, adaptacja, niepełnosprawność

\section{Introduction}

The literature of the subject includes different definitions of physical activity (PA) [1-4]. It is described as every movement performed by skeletal muscles above resting metabolic rate. According to the statistical data gathered by the Central Statistical Office (CSO) in 2013, the participation in sports or recreational activities was declared by $45.9 \%$ of the Polish population [5].

Physical activity (PA) is important for children and youth as it contributes to appropriate emotional, social and somatic development. A decreased level of PA in childhood may lead to negative changes in the musculoskeletal system later in life, e.g. to the loss of the cortical bone in adulthood [6] or to obesity [7]. It was proved that PA stimulates physical and motor development and improves functional capabilities and mental state but, first and foremost, it prevents or delays the development of lifestyle diseases, e.g. it reduces the risk of coronary heart disease [8]. It is alarming that the level of PA among the youngest society members decreases with age and is lower than the recommendations of the World Health Organization (WHO). For instance, it was revealed that the majority of children and youth with type 1 diabetes mellitus are not physically active [8]. According to the recommendations, school-age children should perform moderateand high-intensity physical activity for at least 60 minutes a day. Currently, the development of such technologies as mobile phones, the Internet and computers is the main reason why contemporary children and youth demonstrate lower levels of physical activity than their counterparts from the end of the 1990s [9].

Physical activity may also be limited by developmental disorders, diseases and disabilities. According to the WHO, disability is defined as "any restriction or lack (resulting from an impairment) of ability to perform an activity in the manner or within the range considered normal for a human being". In 2014, approximately $18 \%$ of the society had diagnosed disabilities [10].

Moving around, using urban infrastructure or taking up PA may be difficult for people with disabilities. In order to meet their needs, improvements aimed at helping them to participate in daily life at a level similar to people without disabilities are implemented. Through complex activities, physical activity (extra PA in particular) may not only improve motor abilities and physical fitness of children, but may also influence their social sphere of life [11]. Therefore, PA is often highlighted as a significant element in the process of rehabilitation of children and youth with disabilities. Thus, the aim of the work was to review literature regarding differences in physical activity performed by children and youth with typical development and children with disabilities. Moreover, in order to be able to support children with disabilities in the process of rehabilitation and motivate them to 
take up extra PA, we reviewed the literature to find factors which affect the frequency of such PA in children with disabilities.

\section{Material and methods}

The literature review was made with the use of PubMed (Medline) and EBSCO (Academic Search Complete, Health Source, MEDLINE, SPORTDiscus with Full Text, AHFS Consumer Medication Information) databases. The study inclusion criteria were as follows: publication in the English, Spanish or Polish language (1), abstract and/or title of the work included phrases "physical activity" and "children" and "disability" or "children with disabilities" and "fitness" and "activity" or "performance" and "children with disabilities" and "physical activity" (2), the work was published in the years 2011-2018 (3), it is available as a full-text article (4) and it comes from a scientific journal (5).

\section{Results}

As a result of the literature review, 516 articles were found, out of which 35 met all the inclusion criteria (figure 1). They are presented in tables 1 and 2 ( 27 original articles and 8 reviews, respectively).

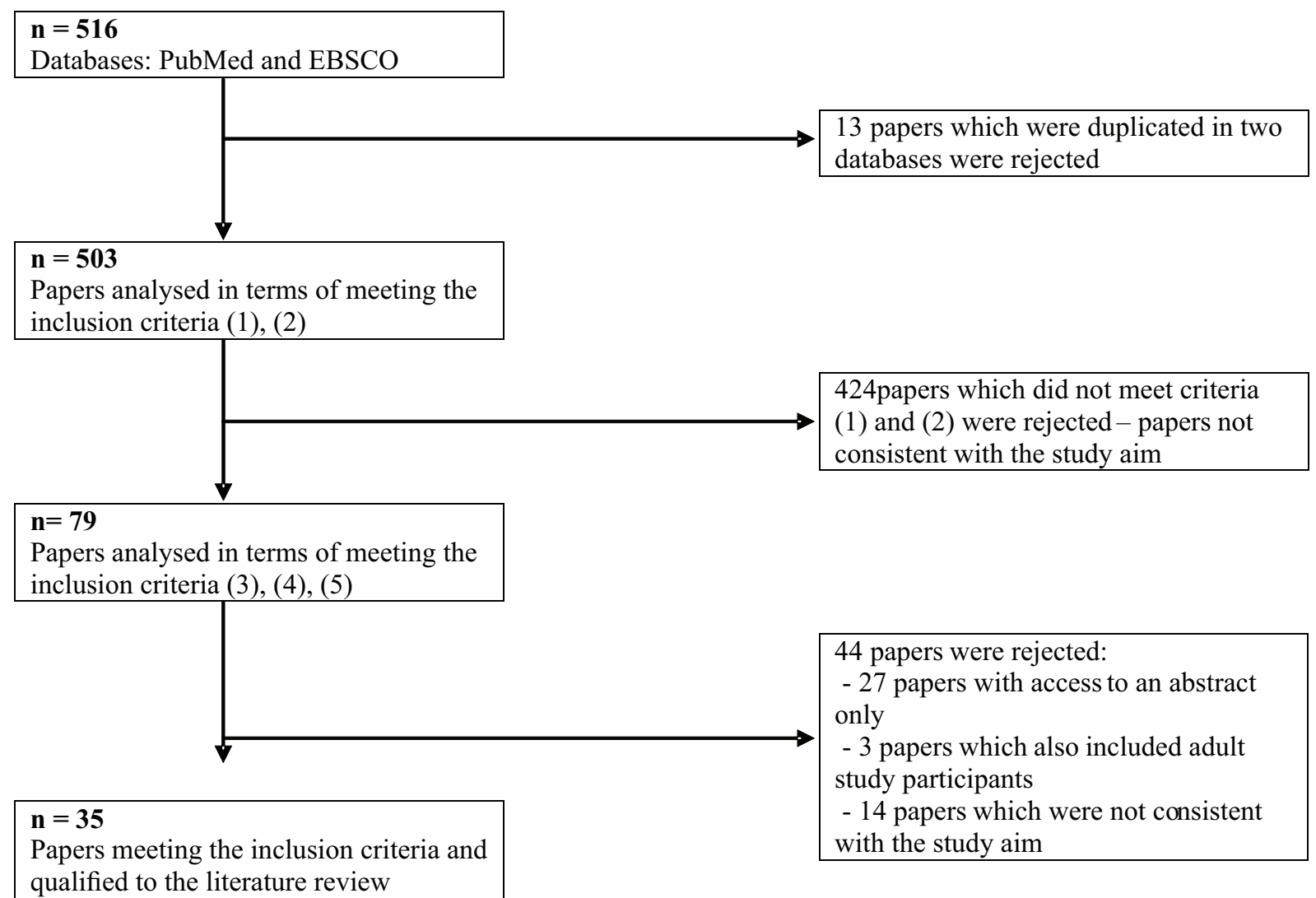

Fig. 1. The scheme of article search and qualification to the literature review 
Tab. 1. The list of research articles on PA in the group of children with disabilities

\begin{tabular}{|c|c|c|c|c|}
\hline $\begin{array}{l}\text { Author } \\
\text { (year) }\end{array}$ & Study aim & Research group & Research methods & Results and conclusions \\
\hline $\begin{array}{l}\text { Bendixen } \\
\text { et al. }(2012)\end{array}$ & $\begin{array}{l}\text { To examine time spent } \\
\text { in a physically active } \\
\text { manner among boys with } \\
\text { Duchenne dystrophy }\end{array}$ & $\begin{array}{l}50 \mathrm{~B} \\
\text { with DMD, } 25 \\
\text { healthy } \mathrm{B}, 5-15 \\
\text { years }\end{array}$ & $\begin{array}{l}\text { Children's Assessment of } \\
\text { Participation and Enjoyment } \\
\text { (CAPE), Pediatric Quality } \\
\text { of Life Inventory } 4.0 \\
\text { (PedsQL } \\
\text { TM 4.0) }\end{array}$ & $\begin{array}{l}\text { Participation in PA was lower in the group of boys } \\
\text { with DMD than in boys with TD. Boys with DMD } \\
\text { manifested lower levels of physical activity. }\end{array}$ \\
\hline $\begin{array}{l}\text { Calley } \\
\text { et al. }(2012)\end{array}$ & $\begin{array}{c}\text { To measure activity, } \\
\text { participation and quality } \\
\text { of life in children with } \mathrm{CP} \\
\text { and to compare them with } \\
\text { children with TD }\end{array}$ & $\begin{array}{c}38(11 \mathrm{~B}, 8 \mathrm{G} \\
\text { with } \mathrm{CP}, \text { the same } \\
\text { number without } \mathrm{CP}) \\
5-12 \text { years }\end{array}$ & \begin{tabular}{|c|} 
Activity - Pediatric \\
Activity Card Sort \\
(PACS), \\
6-Minute Walk Test \\
(6MWT), Timed Up and \\
Go Test (TUG) \\
Participation - LIFE-H \\
QoL - Cerebral \\
Palsy Quality of Life \\
Questionnaire
\end{tabular} & $\begin{array}{l}\text { Higher activity, participation and quality of life were } \\
\text { noted in children with TD than in those with CP. More } \\
\text { attention should be paid to children with disabilities } \\
\text { and therapeutic interventions should be implemented } \\
\text { in order to improve their functional state. }\end{array}$ \\
\hline $\begin{array}{l}\text { Van Wely } \\
\text { et al. (2012) }\end{array}$ & $\begin{array}{l}\text { To assess activity of } \\
\text { children with bilateral } \\
\text { spastic CP }\end{array}$ & $\begin{array}{c}62(39 \mathrm{~B}, 23 \mathrm{G} \text { with } \\
\mathrm{CP}), 7-13 \text { years }\end{array}$ & $\begin{array}{l}\text { StepWatch Activity } \\
\text { Monitor (SAM) }\end{array}$ & $\begin{array}{c}\text { Children took more steps during school days than } \\
\text { during weekend days. Physical activity at the weekend } \\
\text { should be increased among children with CP. }\end{array}$ \\
\hline $\begin{array}{l}\text { Kwan et al. } \\
\quad(2013)\end{array}$ & $\begin{array}{l}\text { Children with DCD } \\
\text { (Developmental } \\
\text { coordination disorder) }\end{array}$ & $\begin{array}{l}61 \mathrm{~B}(19 \\
\text { with DCD and } 42 \\
\text { without DCD) }\end{array}$ & $\begin{array}{l}\text { Questionnaires, } \\
\text { accelerometer }\end{array}$ & $\begin{array}{l}\text { The research confirmed decreased physical activity } \\
\text { in boys with CDC compared to boys with TD and its } \\
\text { correlation with cognitive abilities. }\end{array}$ \\
\hline $\begin{array}{l}\text { Michelsen } \\
\text { et al. (2013) }\end{array}$ & $\begin{array}{c}\text { To evaluate the frequency } \\
\text { of participation in social } \\
\text { life and PA among } \\
\text { adolescents with CP }\end{array}$ & $\begin{array}{c}667 \text { adolescents } \\
\text { with CP, } 4666 \\
\text { adolescents with TD, } \\
13-17 \text { years }\end{array}$ & $\begin{array}{c}\text { Questionnaire of Young } \\
\text { People's Participation } \\
\text { (QYPP) }\end{array}$ & $\begin{array}{l}\text { Adolescents with CP spent less time with friends and } \\
\text { were less independent in daily life than their peers; } \\
\text { they spent less time doing sports but played electronic } \\
\text { games as often as their peers. }\end{array}$ \\
\hline $\begin{array}{l}\text { Verschuren } \\
\text { et al. (2013) }\end{array}$ & \begin{tabular}{|c|} 
To compare anaerobic \\
capacity in children with \\
spastic CP who walk \\
without support \\
with children with TD, \\
GMFCS I-II \\
\end{tabular} & $\begin{array}{c}159 \text { children }(102 \\
\text { B, } 57 \mathrm{G}) \text { with } \mathrm{CP} \\
\text { and } 376(175 \mathrm{~B}, 201 \\
\mathrm{G}) \text { children with TD; } \\
\text { mean age B: CP - } \\
9.7, \mathrm{TD}-8.9\end{array}$ & \begin{tabular}{|c|} 
The Muscle Power Sprint \\
Test (MPST)
\end{tabular} & $\begin{array}{l}\text { Anaerobic performance was lower in children with CP } \\
\text { than in children with TD. Differences between children } \\
\text { with CP and TD increased with height, particularly in } \\
\text { children with CP classified at GMFCS level II. }\end{array}$ \\
\hline $\begin{array}{l}\text { Conchar } \\
\text { et al. }(2014)\end{array}$ & $\begin{array}{c}\text { To assess the participation } \\
\text { of South African } \\
\text { adolescents with CP in } \\
\text { physical activity }\end{array}$ & $\begin{array}{l}15 \text { adolescents, } 12- \\
18 \text { years }\end{array}$ & $\begin{array}{l}\text { Interviews transcribed } \\
\text { and analysed with the } \\
\text { use of Interpretative } \\
\text { Phenomenological } \\
\text { Analysis (IPA) }\end{array}$ & $\begin{array}{l}\text { The participants declared that their ability to engage } \\
\text { in sports and effort depends on their physical } \\
\text { limitations. There also exist psychological, social and } \\
\text { environmental correlations with PA. }\end{array}$ \\
\hline $\begin{array}{l}\text { Mitchell } \\
\text { et al. (2014) }\end{array}$ & $\begin{array}{c}\text { To assess the correlations } \\
\text { of physical, personal and } \\
\text { environmental features } \\
\text { with the level of PA in } \\
\text { children with cerebral } \\
\text { palsy }\end{array}$ & \begin{tabular}{|}
102 children $(52 \mathrm{~B}$, \\
$50 \mathrm{G})$ \\
with unilateral $\mathrm{CP}$, \\
8-17 years
\end{tabular} & $\begin{array}{c}\text { ActiGraph - } \\
\text { accelerometer, } \\
\text { 6-minute test (6MWT), } \\
\text { Participation and } \\
\text { Environment Measure } \\
\text { for Children and Youth } \\
\text { (PEM-CY) }\end{array}$ & $\begin{array}{c}\text { Younger age, male sex, increased performance in the } \\
6 \mathrm{MWT} \text {, increased participation at home and in the } \\
\text { society (PEM-CY) were significantly associated with } \\
\text { PA counts. }\end{array}$ \\
\hline $\begin{array}{l}\text { Obeid } \\
\text { et al. }(2014)\end{array}$ & $\begin{array}{c}\text { To measure sedentary } \\
\text { time and frequency } \\
\text { of breaks interrupting } \\
\text { sedentary time in youth } \\
\text { with CP compared with } \\
\text { youth with TD, GMFCS } \\
\text { I-III } \\
\end{array}$ & $\begin{array}{l}17 \text { children with } \mathrm{CP} \\
\text { and } 17 \text { children with } \\
\mathrm{TD} ; 15 \mathrm{~B}, 2 \mathrm{G} \text { in } \\
\text { each of the groups, } \\
\text { children with } \mathrm{CP}\end{array}$ & $\begin{array}{l}\text { Accelerometer above } \\
7 \text { days. Time spent in } \\
\text { a sedentary position in } \\
\text { minutes and number of } \\
\text { breaks were calculated }\end{array}$ & $\begin{array}{l}\text { Children with CP engaged in significantly more } \\
\text { sedentary time }(47.5 \mathrm{~min} / \mathrm{h}) \text { and had fewer breaks } \\
\text { (179) than children with } \mathrm{TD}(43.6 \mathrm{~min} / \mathrm{h} \text { and } 232 \text {, } \\
\text { respectively). Sedentary time was longer and there } \\
\text { were fewer breaks in the group of children with } \mathrm{CP} \text {. }\end{array}$ \\
\hline $\begin{array}{l}\text { Bloemen } \\
\text { et al. (2015) }\end{array}$ & $\begin{array}{c}\text { To summarise factors } \\
\text { increasing the level of PA } \\
\text { among children and youth } \\
\text { with PD }\end{array}$ & $\begin{array}{c}33 \text { children and } \\
\text { youth with SB, } \\
\text { parents, } 8-18 \text { years } \\
\text { (children and youth) }\end{array}$ & $\begin{array}{l}\text { Physical Activity for } \\
\text { Persons with } \\
\text { a Disability (PAD), } \\
\text { interview with } \\
\text { participants }\end{array}$ & $\begin{array}{l}\text { Personal and environmental factors were the main } \\
\text { factors responsible for the presented level of PA } \\
\text { indicated by the youth with PD. }\end{array}$ \\
\hline $\begin{array}{l}\text { Bohr et al. } \\
\quad(2015)\end{array}$ & \begin{tabular}{|} 
The participation in PA \\
was examined taking into \\
account sex, pain, disease \\
activity and functional \\
ability of children with JIA
\end{tabular} & $\begin{array}{l}133(99 \mathrm{G}, 34 \mathrm{~B}) \\
7-20 \text { years }\end{array}$ & Accelerometer for 7 days & $\begin{array}{l}\text { The level of PA was lower among children and youth } \\
\text { with Juvenile Idiopathic Arthritis than in their peers. }\end{array}$ \\
\hline
\end{tabular}




\begin{tabular}{|c|c|c|c|c|}
\hline $\begin{array}{l}\text { Kolehmainen } \\
\text { et al. }(2015)\end{array}$ & $\begin{array}{l}\text { To identify body } \\
\text { function and structure, } \\
\text { activity, environmental } \\
\text { and personal factors } \\
\text { related to participation } \\
\text { in physical play/leisure } \\
\text { among CYPD }\end{array}$ & 17 CYPD, 6-8 years & $\begin{array}{l}\text { Children's Assessment } \\
\text { of Participation and } \\
\text { Enjoyment (CAPE), } \\
\text { therapist's assessment }\end{array}$ & $\begin{array}{l}\text { The examined children wanted to participate in PA but } \\
\text { their disability and parents were significant limiting } \\
\text { factors. The main reasons for limiting PA were parents } \\
\text { (fear of injury, perceiving a child as insufficiently fit, } \\
\text { family lifestyle) and the disability itself. }\end{array}$ \\
\hline $\begin{array}{l}\text { Marques } \\
\text { et al. (2015) }\end{array}$ & $\begin{array}{c}\text { To explore psychosocial } \\
\text { correlations of PA among } \\
\text { children and adolescents } \\
\text { with spina bifida }\end{array}$ & $\begin{array}{c}31(15 \mathrm{~B}, 16 \mathrm{G}), 10- \\
17 \text { years }\end{array}$ & $\begin{array}{l}\text { Questionnaire collecting } \\
\text { data on PA, demography } \\
\text { and psychosocial } \\
\text { variables }\end{array}$ & $\begin{array}{l}38.7 \% \text { reported to participate in both organized and } \\
\text { non-organized physical activity. The majority of } \\
\text { children did not participate in PA regularly. }\end{array}$ \\
\hline $\begin{array}{l}\text { Ryan et al. } \\
\text { (2015) }\end{array}$ & $\begin{array}{c}\text { To compare patterns } \\
\text { of PA and sedentary } \\
\text { behaviour between } \\
\text { children with CP and TD, } \\
\text { GMFCS I-III }\end{array}$ & $\begin{array}{c}33 \text { children with } \mathrm{CP} \\
\text { and } 33 \text { children with } \\
\text { TD }-17 \mathrm{~B}, 17 \mathrm{G} \text { in } \\
\text { each group: } 6-10 \\
\text { years }\end{array}$ & $\begin{array}{c}\text { RT3 - accelerometer } \\
\text { above } 7 \text { days }\end{array}$ & $\begin{array}{l}\text { Children with CP spent more time sitting and less } \\
\text { time participating in PA. It is important to promote } \\
\text { PA among children with CP from early childhood and } \\
\text { enable them to participate in sport. }\end{array}$ \\
\hline $\begin{array}{l}\text { Shields et al. } \\
\quad(2016)\end{array}$ & $\begin{array}{l}\text { To examine barriers and } \\
\text { facilitators concerning } \\
\text { participation in PA among } \\
\text { children with disabilities }\end{array}$ & \begin{tabular}{|}
10 groups, 63 \\
participants $(23$ \\
children with \\
disabilities, 20 \\
parents, 20 sport \\
and recreation staff, \\
children $10-18$ years
\end{tabular} & \begin{tabular}{|} 
Interview with \\
participants, observation
\end{tabular} & $\begin{array}{c}\text { Important barriers to participation in PA included the } \\
\text { lack of family support and limited access to equipment } \\
\text { properly adapted to the needs of individuals with } \\
\text { disabilities. }\end{array}$ \\
\hline $\begin{array}{l}\text { Degerstedt } \\
\text { et al. (2017) }\end{array}$ & $\begin{array}{l}\text { To analyse how PTI } \\
\text { and PA are allocated for } \\
\text { children with CP }\end{array}$ & $\begin{array}{c}313 \text { children }(172 \\
\mathrm{B}, 141 \mathrm{G}) \text { with } \mathrm{CP} \\
6-11 \text { years }\end{array}$ & \begin{tabular}{|} 
Cerebral Palsy follow-Up \\
Program (CPUP), \\
Gross Motor Function \\
Classification System \\
(GMFCS)
\end{tabular} & $\begin{array}{c}\text { Physiotherapists were involved more often with } \\
\text { children who had lower motor function. Children } \\
\text { with a lower intellectual level participated in PA less } \\
\text { frequently. Further research is needed to ensure fair } \\
\text { interventions. }\end{array}$ \\
\hline $\begin{array}{l}\text { Li et al. } \\
(2017)\end{array}$ & $\begin{array}{l}\text { To assess PA of children } \\
\text { with PD in school and } \\
\text { home settings }\end{array}$ & $\begin{array}{c}35 \text { children (26 B, } 7 \\
\text { G) with PD }\end{array}$ & $\begin{array}{l}\text { BEACHES (Behaviors } \\
\text { of Eating and Activity } \\
\text { for Children's Health: } \\
\text { Evaluation System) }\end{array}$ & $\begin{array}{c}\text { Children spent the majority of time being physically } \\
\text { inactive, but had more PA during breaks and lunch } \\
\text { break. This study confirmed how little PA children with } \\
\text { PD have in school settings. }\end{array}$ \\
\hline $\begin{array}{l}\text { Tristani } \\
\text { et al. }(2017)\end{array}$ & $\begin{array}{l}\text { To assess the theoretical } \\
\text { content of PA information } \\
\text { targeting parents of } \\
\text { children with disabilities } \\
\text { (CYWD) }\end{array}$ & Websites & $\begin{array}{l}\text { Content Analysis } \\
\text { Approach to Theory- } \\
\text { specified Persuasive } \\
\text { Educational } \\
\text { Communication } \\
\text { (CAATSPEC) }\end{array}$ & $\begin{array}{l}\text { Over half of the knowledge-based information included } \\
\text { suggestions and guidelines regarding PA. This research } \\
\text { highlights the gaps between theory and practice, } \\
\text { emphasizing the need for better knowledge-translation } \\
\text { practices. }\end{array}$ \\
\hline $\begin{array}{l}\text { Wojtkowski } \\
\text { et al. (2017) }\end{array}$ & $\begin{array}{l}\text { To compare the quality } \\
\text { of life of CYPD and } \\
\text { healthy children } \\
\text { assessed by parents }\end{array}$ & $\begin{array}{c}105 \text { children }(57 \mathrm{~B}, \\
48 \mathrm{G}), 5-18 \text { years } \\
\text { parents }\end{array}$ & $\begin{array}{l}\text { Child Health } \\
\text { Questionnaire - Parent } \\
\text { Form ( BQ-PF28) }\end{array}$ & $\begin{array}{l}\text { Lower quality of life of CYPD compared with } \\
\text { the control group, both in terms of physical and } \\
\text { psychosocial health. }\end{array}$ \\
\hline $\begin{array}{l}\text { Wyszyńska } \\
\text { et al. } \\
\text { (2017) }\end{array}$ & $\begin{array}{l}\text { Correlation between PA } \\
\text { and HPT }\end{array}$ & $\begin{array}{c}568(285 \mathrm{~B}, 283 \mathrm{G} \\
\text { with ID, the same } \\
\text { number without ID) } \\
7-18 \text { years }\end{array}$ & $\begin{array}{l}\text { PORTSTAND } 210 \\
\text { portable stadiometer, } \\
\text { sphygmomanometer. } \\
\text { Physical Activity } \\
\text { Questionnaire for Older } \\
\text { Children (PAQ-C) } \\
\end{array}$ & $\begin{array}{l}\text { The level of PA was significantly lower in the study } \\
\text { group than in the control group. A low level of PA in } \\
\text { children with ID was related to a higher risk of HPT. }\end{array}$ \\
\hline $\begin{array}{l}\text { Van den } \\
\text { Heuvel et al. } \\
\quad(2017)\end{array}$ & $\begin{array}{l}\text { To examine the potential } \\
\text { of IROMEC robot in } \\
\text { rehabilitation and special } \\
\text { education for CYPD }\end{array}$ & $\begin{array}{l}25 \text { children } \\
\text { with parents }\end{array}$ & $\begin{array}{l}\text { Individual interviews, } \\
\text { group interviews, } \\
\text { questionnaire } \\
\text { Robot IROMEC }\end{array}$ & $\begin{array}{c}\text { The existing play scenarios of IROMEC have the } \\
\text { potential to support play for children with severe } \\
\text { physical disabilities, especially in the domains of } \\
\text { movement functions, learning and applying knowledge } \\
\text { and communication. The results of this study can } \\
\text { be used to further develop meaningful robotic play } \\
\text { interventions for CYPD. }\end{array}$ \\
\hline $\begin{array}{c}\text { Ionescu } \\
\text { et al. (2018) }\end{array}$ & $\begin{array}{l}\text { To present activities } \\
\text { stimulating active } \\
\text { lifestyle among DC }\end{array}$ & School-age children & $\begin{array}{l}\text { Video created with the } \\
\text { use of a sign language, } \\
\text { books with cartoons, } \\
\text { posters, programme of } \\
\text { school education }\end{array}$ & $\begin{array}{c}\text { Educational tools for children are useful resources. } \\
\text { It is necessary to intensify the efforts aimed at } \\
\text { promoting active lifestyle of DC. }\end{array}$ \\
\hline $\begin{array}{l}\text { Leo et al. } \\
\text { (2018) }\end{array}$ & $\begin{array}{l}\text { To examine PA } \\
\text { preferences and attitudes } \\
\text { of CYPD }\end{array}$ & $\begin{array}{c}38(21 \mathrm{~B}, 17 \mathrm{G}) \\
\text { with PD }\end{array}$ & $\begin{array}{c}\text { 7-day physical activity } \\
\text { questionnaire }\end{array}$ & $\begin{array}{l}\text { Low or moderate level of PA among children with PD. } \\
\text { Swimming is the most frequently chosen type of PA. } \\
\text { Alternative forms of PA for CYPD should be sought. }\end{array}$ \\
\hline $\begin{array}{l}\text { Protic et al. } \\
\quad(2018)\end{array}$ & $\begin{array}{l}\text { To examine the } \\
\text { relationship between PA } \\
\text { and executive functions } \\
\text { among children with ID }\end{array}$ & $\begin{array}{c}104(62 \mathrm{~B}, 42 \mathrm{G}) \\
\text { with ID, 7-18 years }\end{array}$ & $\begin{array}{l}\text { GT3X Actigraph } \\
\text { accelerometer, } \\
\text { Behavior Rating } \\
\text { Inventory of Executive } \\
\text { Functions (BRIEF) }\end{array}$ & $\begin{array}{l}\text { The level of ID was a significant predictive factor } \\
\text { in all the short scales. Future research may focus on } \\
\text { determining appropriate physical activity that would } \\
\text { influence the development of executive functions } \\
\text { among children with ID. }\end{array}$ \\
\hline
\end{tabular}




\begin{tabular}{|c|c|c|c|c|}
\hline $\begin{array}{l}\text { Robertson } \\
\text { et al. (2018) }\end{array}$ & $\begin{array}{c}\text { To compare the } \\
\text { participation in PA by } \\
\text { children with ID in } \\
\text { order to identify socio- } \\
\text { demographic predictors } \\
\text { of participation }\end{array}$ & $\begin{array}{c}\text { Children with ID, } 13- \\
14 \text { years }\end{array}$ & $\begin{array}{l}\text { Secondary analysis of } \\
\text { Next Steps, } \\
\text { educational records }\end{array}$ & $\begin{array}{c}\text { The rate of participation in PA was higher among } \\
\text { participants without ID. Costs, transport and lack of } \\
\text { support were common obstacles in PA participation } \\
\text { among children with ID. }\end{array}$ \\
\hline $\begin{array}{l}\text { Willis et al. } \\
\text { (2018) }\end{array}$ & $\begin{array}{c}\text { To assess how an } \\
\text { intervention increasing } \\
\text { participation in PA makes } \\
\text { it possible for CD to } \\
\text { participate in PA }\end{array}$ & $\begin{array}{c}31(18 \mathrm{~B}, 13 \mathrm{G}), 5-17 \\
\text { years, } 44 \text { parents }\end{array}$ & $\begin{array}{c}\text { Observation of } \\
\text { participation, interviews, } \\
\text { focus groups }\end{array}$ & $\begin{array}{l}\text { Three main mechanisms promoting outcomes: } \\
\text { (1) support and relations: basic mechanism, }(2) \\
\text { participation-focused approach and (3) investing } \\
\text { in the future. }\end{array}$ \\
\hline $\begin{array}{l}\text { Zwinkels } \\
\text { et al. (2018) }\end{array}$ & $\begin{array}{l}\text { To examine the effects } \\
\text { of school-based sports } \\
\text { programme on CYPD }\end{array}$ & $\begin{array}{l}71 \text { children }(39 \mathrm{~B}, \\
32 \mathrm{G}) \text { CYPD, 8-19 } \\
\text { years }\end{array}$ & Muscle Power Sprint Test & $\begin{array}{l}\text { A significant improvement of } 16 \% \text { in favour of the } \\
\text { sport group was found for anaerobic performance. } \\
\text { Anaerobic performance and fat mass improved } \\
\text { following a school-based sports program. These effects } \\
\text { are promising for long-term health promotion. }\end{array}$ \\
\hline
\end{tabular}

Tab. 2. The list of review studies on PA in children with disabilities

\begin{tabular}{|c|c|c|c|c|}
\hline Author (year) & Research group & $\begin{array}{l}\text { Number of studies } \\
\text { in the review }\end{array}$ & Study aim & Results and conclusions \\
\hline $\begin{array}{l}\text { McPherson } \\
\text { et al. (2013) }\end{array}$ & $\begin{array}{l}\text { Children with } \\
\text { physical disabilities } \\
\quad(0-18 \text { years })\end{array}$ & 34 articles & $\begin{array}{l}\text { To analyse interventions aimed } \\
\text { at weight control and PA and } \\
\text { healthy eating habits of children } \\
\text { with physical disabilities }\end{array}$ & $\begin{array}{l}\text { The results of research were based on PA and } \\
\text { regarded internal motivation of a child. Also, an } \\
\text { increased engagement and effort was noted during } \\
\text { strength training. }\end{array}$ \\
\hline $\begin{array}{c}\text { Bloemen } \\
\text { et al. }(2014)\end{array}$ & $\begin{array}{l}\text { Children with } \\
\text { physical disabilities } \\
\text { (4-18 years) }\end{array}$ & $\begin{array}{c}18 \text { (6 qualitative, } 12 \\
\text { quantitative) }\end{array}$ & $\begin{array}{c}\text { To summarise factors associated } \\
\text { with PA of children with physical } \\
\text { disabilities }\end{array}$ & $\begin{array}{l}\text { Factors associated with PA of children with physical } \\
\text { disabilities (age, time, openness, motivation, perfor- } \\
\text { mance, interactions with society, abilities) and envi- } \\
\text { ronmental factors (family, support and contact with } \\
\text { people, sport, school, transport, financial support) } \\
\text { were determined. }\end{array}$ \\
\hline $\begin{array}{l}\text { Kanagasabai } \\
\text { et al. (2014) }\end{array}$ & $\begin{array}{l}\text { Children with } \\
\text { disabilities } \\
\text { (6-12 years) }\end{array}$ & $\begin{array}{l}35 \text { (24 quantitative, } \\
11 \text { qualitative) }\end{array}$ & $\begin{array}{l}\text { To find associations between } \\
\text { motor functioning and leisure } \\
\text { participation of children with } \\
\text { physical disabilities }\end{array}$ & $\begin{array}{c}\text { A low level of leisure participation was correlated } \\
\text { with motor functioning of children with physical } \\
\text { disability. The higher the level of motor functioning, } \\
\text { the higher the level of physical activity. }\end{array}$ \\
\hline $\begin{array}{l}\text { Rowland } \\
\text { et al. (2015) }\end{array}$ & $\begin{array}{l}\text { Children with phys- } \\
\text { ical disabilities and } \\
\text { limitations in lower } \\
\text { extremity function }\end{array}$ & 8 articles & $\begin{array}{l}\text { To explore the utility of active } \\
\text { video gaming (AVG) as a means } \\
\text { of reducing sedentary behaviour } \\
\text { and increasing PA among youth } \\
\text { with physical disabilities }\end{array}$ & $\begin{array}{c}\text { AVG adapted to the needs of children are an ex- } \\
\text { cellent form of rehabilitation, functional rehabili- } \\
\text { tation and physical activation aimed at improving } \\
\text { the quality of life and life parameters. AVG, as an } \\
\text { accessible option, have the potential to increase PA } \\
\text { participation. }\end{array}$ \\
\hline $\begin{array}{l}\text { Bloemen } \\
\text { et al. (2017) }\end{array}$ & $\begin{array}{c}\text { Children with PD } \\
\text { 4-18 years }\end{array}$ & 7 studies & $\begin{array}{l}\text { To summarize the best evidence } \\
\text { of interventions for increasing PA } \\
\text { in children with PD }\end{array}$ & $\begin{array}{c}\text { There is evidence for no effect of physical training } \\
\text { on objectively measured physical activity in children } \\
\text { with PD. Increasing PA in children with PD is very } \\
\text { complex and demands further development and } \\
\text { research. }\end{array}$ \\
\hline $\begin{array}{l}\text { Frey et al. } \\
\quad(2017)\end{array}$ & $\begin{array}{c}\text { Youth with ID aged } \\
0-18\end{array}$ & 213 articles & $\begin{array}{l}\text { To describe interventions de- } \\
\text { signed to promote PA for youth } \\
\text { with ID }\end{array}$ & $\begin{array}{c}\text { Nine studies reported significant increases in } \\
\text { physical activity behaviour. It was well documented } \\
\text { that youth with ID are less active than individuals } \\
\text { without disabilities. }\end{array}$ \\
\hline $\begin{array}{l}\text { Arbour-Nici- } \\
\text { topoulos } \\
\text { et al. }(2018)\end{array}$ & $\begin{array}{l}\text { Children and youth } \\
\text { with PD (mean age } \\
\quad \leq 18 \text { years) }\end{array}$ & $\begin{array}{l}17 \text { studies (quali- } \\
\text { tative-9, quantita- } \\
\text { tive- } 5 \text {, mixed-3) }\end{array}$ & $\begin{array}{c}\text { To comprehensively evaluate } \\
\text { inclusive out-of-school time PA } \\
\text { programs for children/youth with } \\
\text { PD }\end{array}$ & $\begin{array}{c}\text { Outcomes focused on social skills/relationships, } \\
\text { physical skill development, and psychological } \\
\text { well-being, with overall positive effects shown in } \\
\text { these areas. }\end{array}$ \\
\hline $\begin{array}{l}\text { McGarty } \\
\text { et al. (2018) }\end{array}$ & $\begin{array}{l}\text { Children and youth } \\
\text { with ID }(<18 \text { years })\end{array}$ & 5 articles & $\begin{array}{l}\text { To systematically review how } \\
\text { effective interventions are at } \\
\text { increasing PA levels in children } \\
\text { and adolescents with ID }\end{array}$ & $\begin{array}{c}\text { Interventions did not support sufficient changes } \\
\text { in PA to improve health. There is a lack of studies } \\
\text { which aim to increase PA levels in children and } \\
\text { adolescents with ID. }\end{array}$ \\
\hline
\end{tabular}




\section{Discussion}

The aim of the work was to review literature regarding differences in physical activity of children and youth with typical development and children with disabilities. Moreover, in order to be able to support children with disabilities in the process of rehabilitation and motivate them to take up extra PA, we reviewed the literature to find factors which affect the frequency of such PA in children with disabilities.

In the last two years, 82 papers devoted to physical activity of children and youth with disabilities have been published. Researchers highlight the fact that the level of PA should be monitored, new and interesting programmes that would encourage children and youth to take up PA should be developed and the barriers they noticed should be removed.

While evaluating children with disabilities, researchers often compared them with children with typical development (TD) [12-15]. Higher levels of PA were noted among healthy children, while those with disabilities manifested both lower levels of PA and a lower quality of life. Van Weley et al. (2012) and Ryan et al. (2015) focused on presenting the levels of daily PA of children and youth with cerebral palsy depending on age. The authors concluded that age and the level of disability are the main reasons for lower levels of PA [16-17]. Early school-age children should participate in a big number of sports classes and perform various types of physical activity at different levels of intensity since their bodies adapt to effort during such activities. This is the time when children develop their motor coordination, social contacts with their peers and, what is more important, their PA performed at such an early age influences their willingness to do PA also in older age. Thus, it is so important to encourage children to take up PA early. It is particularly significant in children with disabilities who have more scruples or limitations that make them reluctant to participate in sports. Encouraging and enabling them to participate in PA (applying various adaptations) and making sure they spend as little time as possible in a sedentary position constitute a part of the rehabilitation process, which, in consequence, positively influences their health state or increases the amount of social contacts with peers [18].
Recently, there have appeared numerous papers showing the influence of intervention programmes aimed at increasing the incidence of PA in children with disabilities [19-27]. The studies show that children are not always rightly granted auxiliary or counselling benefits regarding physical activity [26]. Also, activities promoting an active lifestyle need to be intensified [24] and there is a need for better practices related to passing the knowledge from the field of physical culture to parents and their children [21]. Publications which are systematic literature reviews indicate that the programmes of extra-curricular activities are important for positive development of psycho-social and physical skills of children with disabilities [23]; however, increasing PA in this group is very complex and requires further research [28].

A reduced interest in the participation in sports and leisure time PA was noted among youth with disabilities and older children. In order to encourage this group to take up PA, Maher et al. (2014) examined children and youth with disabilities with regard to their PA. The authors prepared an experimental training programme based on recreational tasks. It turned out that young people became interested in taking up PA. Even after the experiment completion, the study participants tried to maintain PA at the level higher than the one from before the research [29]. It is worth implementing a programme that makes the youth with disabilities aware of the benefits of PA.

Kanagasabai et al. (2014) made a review of scientific papers regarding the correlations between PA and functional levels of children with disabilities aged 6-12. The research results gathered by the authors revealed that it is enough to adapt a game or play to children manifesting various levels of physical fitness to make them more eager to participate in sports activities [30]. The literature review revealed that instead of electronic games or the Internet, children with disabilities should try various forms of PA [31-34].

The lack of PA both among healthy children and in children with disabilities leads to diseases of the osseous and cardiovascular system and to a considerable loss of anaerobic capacity, which, in turn, decreases their quality of life. Children who do not perform PA manifest lower anaerobic capacity [35-38]. Such people do not often realise the harmfulness of their decision as their deteriorating health regards mainly phenomena inside the body. 
One of the symptoms of such a state, which is more and more often observed in the society, is obesity. McPherson et al. (2013) showed the ways of preventing obesity and controlling weight. The majority of the presented methods of dealing with obesity involved taking up extra physical activity. Children paid particular attention to strength exercises. It may have been caused by the fact that high-intensity physical exercises help to develop anaerobic capacity which is often more useful in the case of people with disabilities than aerobic capacity in the case of people with disabilities [36].

Despite such a significant role of PA in the life of individuals with disabilities, a low percentage of the youth do sports. Such environmental obstacles as architectural, urban, transport or technical barriers are regarded as reasons for this situation [39]. Bloemen et al. (2014) carried out a review of literature concerning studies on factors related to the participation in PA. It was observed that a limited access to equipment and facilities and the level of disability led to the fact that children performed PA less frequently [40]. The authors revealed that their worse image in the society, insufficient support of family and close friends, limited access to transport and the lack of knowledge about the possibilities to participate in sports have been playing a significant role and have constituted the reason for the lower participation in PA among children with disabilities [41-45]. On the other hand, it was observed that despite their disabilities that cause various complaints, children are aware of their functional capabilities and make use of available facilities to do sports or take up extra PA [46-47].

\section{Conclusions}

There is a clear difference regarding PA between children and youth with and without disabilities. Its level is considerably lower and it is taken up much less frequently by individuals with disabilities than by persons with typical development. In order to assess PA of children and youth with disabilities, accelerometers, endurance tests, participation and quality of life questionnaires and interviews are most often applied [48-49]. The most important factors influencing the frequency of participation in physical activity include social, psychological and physical barriers such as no access to properly adapted equipment or not adapted surroundings, no motivation of a person with disabilities, inactive lifestyle of a family, social exclusion, a high level of disability connected with a low level of motor functioning. Constant monitoring of literature in this field is recommended due to the fact that numerous researchers have recently written many important papers and they simultaneously highlighted that the level of PA among children with disabilities should be monitored and new and interesting programmes of PA should be developed, while the barriers they noticed should be removed.

\section{References}

1. Anshel MH, Freedson P, Hamill J, Haywood K, Horvat M, Plowman SA. Dictionary of the sport and exercise sciences, Champaign, Illinois. In: Osiński W, ed. Antropomotoryka. Poznań: Akademia Wychowania Fizycznego im. Eugeniusza Piaseckiego; 2003. p. 320.

2. Caspersen CJ, Powell KE, Christenson GM. Physical activity, exercise and physical fitness: definitions and distinctions for health-related research. In: Osiński W, ed. Antropomotoryka. Poznań: Akademia Wychowania Fizycznego im. Eugeniusza Piaseckiego; 2003. p. 320.

3. Osiński W. Antropomotoryka. Akademia Wychowania Fizycznego im. Eugeniusza Piaseckiego: Poznań; 2003.

4. Howley ET, Franks BD. Health Fitness Instructors. Handbook. Chapaign. In: Osiński W, ed. Antropomotoryka. Poznań: Akademia Wychowania Fizycznego im. Eugeniusza Piaseckiego. p. 320.

5. GUS.org Uczestnictwo Polaków w Sporcie i Rekreacji Ruchowej; c2012 [cyt. 2017, 13 czerwiec]. Available at: www.stat.gov.pl/obszary-tematyczne/kultura-turystyka-sport/sport/uczestnictwopolakow-w-sporcie-i-rekreacji-ruchowej-w2012-r-,4,2.html.

6. Kopiczko A, Gryko K, Łopuszańska-Dawid M, Laskin JJ. The incidence of osteopenia among men with different levels of physical activity. Adv Rehab. 2018;2:5-11.

7. Świst A, Graff K, Chałubińska D, Zielińska A, Łukaszewska A. The effects of interventions implemented during a rehabilitation camp on changes in motor skills parameters and body mass in patients with simple obesity. Adv Rehab. 2017;3:5-15.

8. Urniaż AJ. Physical activity and the level of HbAlc in children and adolescents with type 1 diabetes mellitus. Adv Rehab. 2018;3:19-26. 
9. Mazur J, Oblacińska A, Jodkowska M, Małkowska-Szkutnik A, Tabak I, Zawadzka D, Dzielska A, Stalmach M, Radiukiewicz K. Aktywność Fizyczna Młodzieży Szkolnej w wieku 9-17 lat: aktualne wskaźniki, tendencje ich zmian oraz wybrane zewnętrzne i wewnętrzne uwarunkowania. Instytut Matki i Dziecka: Warszawa; 2013.

10. WHO. org c1980 [cyt. 2017, 13 czerwiec]. Available at: www.encyklopedia.pwn.pl/haslo/niepelnosprawnosc;3947453.html.

11. Mędrak A, Piętak J, Łosień T. Wpływ aktywności ruchowej i sportu na rozwój psychomotoryczny dziecka niepełnosprawnego ruchowo. J Educ Health Sport. 2016; 6(7):123-9.

12. Calley A, Williams S, Reid S, Blair E, Valentine J, Girdler S, Elliott C. A comparison of activity, participation and quality of life in children with and without spastic diplegia celebral palsy. Disabil Rehabil. 2012;34(15):130.

13. Bendixen RM, Senesac C, Lott DJ, Vandenborne K. Participation and quality of life in children with Duchenne muscular dystrophy using the International Classification of Functioning, Disability, and Health. Health Qual Life Out. 2012;10:43.

14. Kwan MYW, Cairney J, Hay JA, Faught BE. Understanding physical activity and motivations for children with Developmental Coordination Disorder: An investigation using the Theory of Planned Behaviour. Res Dev Disabil. 2013;34:3691-98.

15. Wyszyńska J, Podgórska-Bednarz J, Dereń K, Mazur A. The Relationship between Physical Activity and Screen Time with the Risk of Hypertension in Children and Adolescents with Intellectual Disability. BioMed Res International. 2017:1-8.

16. Van Wely L, Becher JG, Balemans ACJ, Dallmeijer AJ. Ambulatory activity of children with cerebral palsy: which characteristics are important? Dev Med Child Neurol. 2012; 54:436-42.

17. Ryan JM, Forde C, Hussey JM, Gormley J. Comparison of Patterns of Physical Activity and Sedentary Behaviour Between Children With Cerebral Palsy and Children With Typical Development. Phys Ther. 2015;95:1609-16.

18. Leo J, Faulkner G, Volfson Z, Bassett-Gunter R, Arbour-Nicitopoulos K. Physical Activity Preferences, Attitudes, and Behaviour of Children and Youth With Physical Disabilities. Therapeutic Recreation Journal. 2018; 52(2): 140-153.

19. Willis CE, Reid S, Elliott C, Rosenberg M, Nyquist A, Jahnsen R, Girdler S. A realist evaluation of a physical activity participation intervention for children and youth with disabilities: what works, for home, in what circumstances, and how? BMC Pediatr. 2018; 18:113.

20. Willis C. Nyquist A, Jahnsen R, Elliott C,Ullenhag A. Enabling physical activity participation for children and youth with disabilities following a goal-directed, family-centred intervention. Res Dev Disabil. 2018;77: 30-9.

21. Tristani LK, Bassett-Gunter R, Tanna S. Evaluating Internet-Based Information Physical Activity for Children and Youth With Physical Disabilities. Adapt Phys Act Q. 2017;34: 55-71.

22. McGarty AM, Downs SJ, Melville CA, Harris L. A systematic review and meta-analysis of interventions to increase physical activity in children and adolescents with intellectual disabilities. J Intell Disabil Res. 2018;62(4):312-29.

23. Arbour-Nicitopoulos P, Grassmann V, Orr K. McPherson C, Faulkner E, Wright V. (2018) A Scoping Review of Inclusive Out-of-School Time Physical Activity Programs for Children and Youth With Physical Disabilities. Adapt Phys Act Q. 35(1): $111-38$.

24. Ionescu L, Potora C, Stan O,Lotrean LM. Promotion of an active lifestyle among children with hearing deficiencies - presentation of an educational program. Palestrica of the Third Millennium Civilization \& Sport. 2017; 8(4): 192-195.

25. Frey G, Temple V, Stanish H. Interventions to promote physical activity for youth with intellectual disabilities. SaludPublica Mex. 2017; 59:437-45.

26. Degerstedt F, Wiklund M, Enberg B. Physiotherapeutic interventions and physical activity for children in Northern Sweden with cerebral palsy: a register study from equity and gender perspectives. Global Health Action. 2017; 10: 1-13.

27. Van den Heuvel F, Lexis A, Janssens M, Marti P. Robots supporting play for children with physical disabilities: Exploring the potential of IROMEC. Technol Disabil. 2017; 29(3):109-20.

28. Bloemen M, Van Wely L, Mollema J, Dall Meijer A, De Groot J. Evidence for increasing physical activity in children with physical disabilities: a systematic review. Dev Med Child Neurol. 2017:990-1.

29. Maher C, Crettenden A, Evans K, Thiessen M, Toohey M, Dollman J. A pedometer based physical activity self-management program for children and adolescents with physical disability - design and methods of the StepUp study. BMC Pediatr. 2014;14:31.

30. Kanagasabai PS, Mulligan H, Mirfin-Veitch B, Hale LA. Association between motor functioning and leisure participation of children with physical disability: an integrative review. Dev Med Child Neurol. 2014;56(12):1147-62.

31. Michelsen SI, Flachs EM, Damsgaard MT, Parkers J, Parkinson K, Rapp M, Arnaud C, Nystrand M, Colver A, Fauconnier J, Dickinson HO, Marcelli M, Uldall P. European study of frequency of participation of adolescents with and without cerebral palsy. Eur J of Paediatr Neurol. 2013;18:282-94.

32. Rintaia P, Välimaa R, Tynjälä J, Boyce W, King M, Villberg, Kannas L. Physical Activity of Children With and Without LongTerm Illness or Disability. J Phys Act Health. 2011; 8(8):1066-73.

33. Rowland JL, Malone LA, Fidopiastis CM, Padalabalanarayanan S, Thirumalai M, Rimmer JH. Perspectives on active video gaming as a new frontier in accessible physical activity for youth with physical disabilities. Phys Ther. 2015;96:521-32. 
34. Obeid J, Balemans ACJ, Noorduyn SG, Gorter JW, Timmons BW. Objectively measured sedentary time in youth with cerebral palsy compared with age-, sex-, and season-matched youth who are developing typically: an explorative study. Phys Ther. 2014;94:1163-7.

35. Verschuren O, Maltais DB, Douma-Van Riet D, Kruitwagen C, Ketelaar M. Anaerobic performance in children with cerebral palsy compared to children with typical development. Pediatr Phys Ther. 2013;25(4):409-13.

36. McPherson AC, Keith R, Swift JA. Obesity prevention for children with physical disabilities: A scoping review of physical activity and nutrition interventions. Disabil Rehabil. 2013;36(19):73-87.

37. Zwinkels M, Verschuren O, Balemans A, Lankhorst K, Velde S, Leendert van Gaalen, Janke de Groot, Visser-Meily A. Effects of a School-Based Sports Program on Physical Fitness, Physical activity, and Cardiometabolic Health in Youth With Physical Disabilities. Front Pediatr. 2018;6(75):1-11.

38. Protic M,Valkova $\mathrm{H}$. The relationship between executive functions and physical activity in children with an intellectual disability. J Phys Edu Sport. 2018;18(2):844-952.

39. Grabowski J, Milewska M, Stasiak A. Vademecum organizatora turystyki niepełnosprawnych. WSTH Łódz; 2007.

40. Bloemen MA, Backx FJ, Takken T, Wittink H, Benner J, Mollema J, Groot JF. Factors associated with physical activity in children and adolescents with a physical disability: a systematic review. Dev Med Child Neurol. 2015;57(2):137-48.

41. Shields N, Synnot A. Perceived barriers and facilitators to participation in physical activity for children with disabilities: a qualitative study. BMC Pediatr. 2016;16: 9.

42. Bloemen MA, Verschuren O, Mechelen C, Borst HE., Leeuw AJ, Hoef M, Groot JF. Personal and environmental factors to consider when aiming to improve participation in physical activity in children with Spina Bifida: a qualitative study. BMC Neurol. 2015;15:11.

43. Robertson J, Emerson E, Baines S, Hatton Ch. Self-Reported Participation in Sport/Exercise Among Adolescents and Young Adults With and Without Mild to Moderate Intellectual Disability. J Phys Act Health. 2008;15:247-54.

44. Marques A, Maldonado I, Peralta M, Santos BS, Santos S. Exploring psychosocial correlates of physical activity among children and adolescents with spina bifida. Disabil Health J. 2015;8:123-9.

45. Conchar L, Bantjes J, Swart L, Derman W. Barriers and facilitators to participation in physical activity: The experiences of a group of South African adolescents with cerebral palsy. J Health Psychol. 2014;21(2):152-63.

46. Bohr AH, Nielsen S, Müller K, Pedersen FK, Andersen LB. Reduced physical activity in children and adolescents with Juvenile Idiopathic Arthritis despite satisfactory control of inflammation. Pediatr Rheumatol. 2015; 13: 57.

47. Bult MK, Verschuren O, Lindeman E, Jongmans MJ, Ketelaar M. Do children participate in the activities they prefer? A comparison of children and youth with and without physical disabilities. Clin Rehab. 2014; 28(4): 388-96.

48. Kolehmainen N, Ramsay C, McKee L, Missiunia C, Owen C, Francis J. Participation in physical play and leisure in children with motor impairments: mixed-methods study to generate evidence for developing an intervention. Phys Ther. 2015;95:1374-86.

49. Mitchell LE, Ziviani J. Characteristics associated with physical activity among independently ambulant children and adolescents with unilateral cerebral palsy. Dev Med Child Neurol. 2014;57:167-174.

50. Li R, Sit CH, Yu J, Sum R, Wong S, Cheng K, McKenzie T. Children with Physical Disabilities at School and Home: Physical Activity and Contextual Characteristics. Int J Environ Res Pub Health. 2017;14(7):1-14.

51. Wojtkowski J, Sienkiewicz D, Okurowska-Zawada B, Paszko-Patej G, Konopka A, Okulczyk K, et al. Quality of life of children suffering from motor disabilities as evaluated by their parents. Progress Health Sci. 2017;7(2):60-6. 